\title{
Formation of Russian Policy Towards the Baltic Countries: Historical and Legal Lessons for Modern Ukraine
}

\author{
Oleksandr Ivanov * [0000-0002-5890-5369], Yuriy Ivanov [0000-0003-4901-5337], \\ Volodymyr Okipnyuk [0000-0002-1738-6478] \\ National Academy of Security Service of Ukraine, Kyiv, Ukraine \\ *historyoflaw@ukr.net
}

\begin{abstract}
The article considers the main factors that had created historical prerequisites for development of the Russian expansion in the Baltic States. The main directions of this process are highlighted both in retrospect and at the present stage. The problem of formation of the Estonian community in the Crimea during the times of the Russian Empire in the context of influence on the security aspects of the existence of modern Ukrainian statehood is outlined. The historical preconditions for the formation of the Russian status of the Kaliningrad region as an exclave are determined and the assessment of this phenomenon from the point of view of the stability of the current system of international relations is given. The peculiarities of the Kremlin propaganda's use of falsified facts of the historical and legal reality of Latvia, Lithuania, and Estonia as an instrument of the hybrid war waged against these countries are listed. The factors of spreading Russian expansion in the Baltics are generalized for Ukraine to take into account in the form of a structural model with such basic blocks as: mythologizing the history of the Baltics; religious expansion; the economic importance of the Baltics for Russia; cultural and assimilation policy; foreign policy consolidation of the results of expansion.
\end{abstract}

Keywords: Baltics, Russian expansion, falsification of history, limitrophs, Estonian community of the Crimea, exclave, Kaliningrad region

\section{INTRODUCTION}

During World War II Soviet military leaders proclaimed the need to "push" the front line away from Moscow as a capital of the USSR. To do this the State Defense Committee of the USSR headed by Stalin planned to capture the Baltic countries. Lithuania, Latvia and Estonia were occupied by the Russian Empire in previous centuries. Local regimes were accused of "ingratitude" to the Russian government for the centuries of "prosperity" i.e all of them had been eliminated during well-planned coups. Both in the pre-war period and in the following years, the Soviet authorities proved in all possible ways the "artificiality" of the phenomenon of their own statehood in these countries. However, later they became the first subjects to leave the USSR and to start the process of its desintegration. Despite this, the Russian government still defends its "historic rights" to the Baltics, as well as to Ukraine, trying to maintain its influence there in various ways in order to all the Baltic countries.

\section{HISTORIOGRAPHICAL INFORMATION}

Modern Russian historiography continues imperial and Soviet traditions considering the process of formation of the Baltic states in the context of the clash of Moscow and German spheres of influence, while rejecting any hints of their identity. To denote them as a separate phenomenon, a special term is even used limitrophs [1]. In earlier stages of history that word was used to mark special border provinces of the Roman Empire that were not always formed by the native Romans. Main purpose of their existence was to defend state borders., The Baltic territories were important for Russia for establishing direct trade relations with the Western Europe too. These and other facts remain being of the great strategic importance for the current Russian top political leaders motivating them to carry out subversive activities against Lithuania, Latvia and Estonia. The study of such experience is important for Ukraine not only regarding to the fact that our country is still among the objects of Russian aggression. There are 
also numerous common pages in history of our country and Baltic states, in particular Lithuania. Given the apparent permanence of the state traditions of modern Russia and, consequently, the arsenal of methods of its foreign policy, the study of the historical aspects of its predecessor's expansion into the Baltics is considered to provide insight into the nature of Putin's current encroachments on the independent and sovereign status of Lithuania, Latvia and Estonia.

\section{PRESENTING MAIN MATERIAL}

"Orthodoxy is a kind of spiritual atmosphere of the Russian man", such was the leitmotif of Muscovy's religious policy towards their "native territories" [2]. Calling the Baltics, no other than representatives of the "north-western branch of the Russian people," the Kremlin authorities took great care involve them into the sphere of influence of the Russian Orthodox Church. It caused the myths abo the "natural attraction" of the local population definitely to the Orthodoxy as one of the branches of Christianity. Moreover, some imperial age scholars even derived such a hypothesis from a detailed description of the pre-Christian beliefs of the Baltic ethnic groups. It is significant that the intensification of such research fell mainly on the last decades of the Russian Empire. In those years the real lack of economic and political ties of most of the conquered peoples with the center was revealed. The government was preparing a draft of a large-scale administrative reform but it was too late.

The general concept of Russia's neo-imperial vision of the Baltic's history boils down to the fact that many local ethnic groups have long been pagans, and therefore allegedly alternately came under the influence of various European knightly orders. Due to this background Peter I is considered to be the first tsar who was able to consolidate the stateless peoples under his rule at the beginning of the XVIII century and to provide them with opportunities for full economic and cultural development leveling German influence. Moreover, the lack of alternative facts ensures the susceptibility of this position for both Ukrainian and foreign historians [3]. Thus, theses about "finding artificial grounds for justifying state independence", "constructing one's own history" etc. are being still cultivated within the society because of the banal lack of detailed information about the history of the Baltic countries before the Russian conquest. Although this period is partially revealed in the works of imperial historians, it is done only in the context of confirming the "primordial attraction" of the local population to Muscovy. The whole of ancient Russian history traditionally fits into the general context of Russia, and the contacts of the Kyivan and Novgorod princes with the Baltic leaders are presented as the first well-known facts of the Russian government's interaction with them.

The thesis that the Latvians, Lithuanians and
Estonians allegedly lack their own history remains the basis for Moscow historiography. The main array of works on which the representatives of scientific institutions of modern Russia base their conclusions was created by their colleagues of the imperial era in the first half - the middle of the XIX century. In addition to the actual Russian educational institutions, at that time the autocratic government established many of them in the previously conquered Baltic territories. Paying such attention to the "enlightenment" in this region, tsarist officials explained its proximity to the leading centers of the Western European scientific thought and, accordingly, the expansion of opportunities for interaction with them. At the same time, the practice has shown the establishment of quite powerful mechanisms of interaction between the Baltic and Moscow and St. Petersburg universities in the field of humanities. Declaring triumphantly the supremacy in the discovery of a number of artifacts from the history of the Baltic peoples, Russian scholars "enriched" the list of arguments in favor of their "common historical destiny" with the Russians and the messianic role of the latter towards the Baltics [4].

Denying the existence of separate states in the Baltic states, the Muscovites called them "a natural extension of the Russian state region", in connection with which, they said, there could be no question of any ethnic differences between locals and Russian citizens. At the same time, the semantic load of the term "Russian state field" remains unknown. However, the logic of the Russian rulers provided that in the absence of any natural barriers between their possessions and border lands, the latter could be included with impunity under the scepter of the autocrat. In particular, in the case of the current political situation around the annexation of the Crimea by the Russian Federation, the Kremlin's plans to build a "land corridor" to the new "acquisition through the Southern Ukrainian regions " seem being quite natural. The essential content of the "Russian state field" has nothing similar with the principles of international relations or certain legal categories. Firstly, these are the lands from which Ivan III Kalita collected tribute for the khan during the Golden Horde rule. Secondly, this and other subsequent rulers declared their authority over the former lands of Kyivian Rus. All other annexed territories allegedly had "primordial historical ties" with Moscow economic, religious, cultural and other ones, referring to their extremely important strategic importance as conquered lands.

The history of Russian expansion towards the Baltic peoples is directly connected with the Ukrainian past times. Thus, in particular, after the Crimean War of 1853-1856 mass relocations of Estonians to the Crimea took place. As this confrontation with the Ottoman Empire proved to be a defeat for autocratic Russia, another wave of emigration of Crimean Tatars to the Ottoman Empire had began. In open sources the imperial 
authorities called on the local administration to create the most favorable conditions for leaving the Tatar community. At the same time secret instructions were written to facilitate migration processes. This was evidenced, in particular, by the provisions of the imperial decree of May 22, 1856 to support the large-scale eviction of Crimean Tatars as a "harmful population", later supplemented by secret directives on the certification of emigrants [5]. In addition, Tatar communities also moved in an organized manner in exchange for the rebellious indigenous population to the territory of Serbia, the active process of Russian expansion of which had also taken place at that time. The Crimean territories, which the Russians needed as an industrial and agricultural landfill, remained uninhabited, which was the main reason for the relocation of the Estonian community to the peninsula.

In Russian imperial historiography, there are almost no mentions of Estonian settlements in the Crimea. Instead, a kind of idyll and care of the "king-father" about the fate of the local population is depicted. At the same time, nothing was said about the fact that, despite the early abolition of serfdom in the Baltics, the reform of 1861 led to the strengthening of the position of the Russian nobility in the region, while worsening the position of German landowners. The claims of historians, including domestic ones, about the completely voluntary nature of the resettlement of Estonians to the territory of Crimea seem rather doubtful, as the above-mentioned objective preconditions, supplemented by government persecution of the Malsvetian religious community. Despite official data on the relatively successful resettlement of the Estonian community and their successful economic activities, russification measures have led to the dispersal of ethnic Estonians throughout the Crimea and to the decline in the preservation of national cultural and linguistic traditions. The implementation of traditional for Russian expansionism methods of influencing the national situation in the conquered region in the case of the Baltics was complicated by the relatively low level of susceptibility of its population to propaganda influence. In view of this, the policy of controlled migration has become the most effective solution on the way to the unimpeded development of Estonian lands by Russian landowners.

In the modern occupied Crimea, the Estonian community continues to exist and be numerous, thus being a factor in Russia's influence on the interests of Estonia as an independent state. Formal permits for the existence of national and cultural self-government bodies, holding national holidays and publishing scientific literature on these issues are aimed at distracting the world community from the illegality of actions to annex the Crimea and covertly motivate other countries to recognize it. All the contacts between the Estonian government and the national community in Crimea have been officially suspended. At the same time, after 2014, the popularization of history and culture of the Crimean Estonians has started by means of the printed mass-media and the Internet, as well as thematic concerts and festivals in places of compact residence of this ethnic group in the Russian-occupied territory of the Crimes. Moreover, on April 14, 2015, shortly after the occupation of the Crimea, the self-proclaimed authorities registered the public organization "Regional National-Cultural Autonomy of Estonians of the Republic of Crimea" [6]. Evidently, in this way nothing else is happening but drawing the attention of official Tallinn to the large-scale activities of their compatriots in the Kremlin-occupied sovereign territory of Ukraine. The ultimate goal of such activities may be stated as achievement of the automatic recognition by the Estonian government of the status of Crimea as a Russian territory through the establishment and maintenance of contacts with the above-mentioned public organization. A similar experience took place in the case of Livonia, when in 1569 Ivan the Terrible appointed the self-proclaimed King Magnus to rule this territory from the control of the Kingdom of Poland [7]. As centers of trade, Livonian cities were visited by Western European merchants, and thus the Moscowcontrolled status of the region was effectively recognized by other countries. The situation was similar with the artificial "Ionian Republic" founded in 1798 in Greece, when British troops helped the Russian army to defend in the confrontation with France. Therefore, these and other cases indicate a high probability of repeating a similar scenario regarding the Estonian cultural center in the nowadays Crimea.

Along with the Estonian community, Crimean Tatars also live in the occupied Crimea with the same needs for the development of their own national culture. Historically, both ethnic groups were considered by the Russian occupation authorities in the Crimea as secondary ones, "second-rate" to the Russians. In particular, it is reflected in the existing approaches in Russian historiography to the coverage of the Kremlin's policy towards these peoples. Thus, despite the fact that the Crimean Tatar people, according to all currently recognized classifications, belong to the Turkic group, it is considered by Russian historians separately from the representatives of the latter [8]. The main argument in favor of this position is that the issue of relations with the Crimean Khanate was the subject of negotiations between Russia and the Ottoman Empire, whose vassal, according to long-held opinion in science, was the state of the Crimean Tatars. In this context, in particular, the provisions of the well-known Russian-Turkish KyuchukKaynardzhi Treaty of 1774 on the "independence of the Tatar peoples", allegedly given to them by the tsarist authorities, seemed quite logical. The Estonian people, in turn, as can be concluded from the above, were considered by apologists for autocracy only in the context of the subject of Russian-German relations, also without being given an independent significance in imperial foreign policy. 
Obviously, for modern Putin's Russia, attitudes towards each of these ethnic groups have remained unchanged. In this regard, there is a great basis for intergovernmental cooperation between Ukraine and Estonia, the resource of which would be in the following main areas: joint creation of various scientific institutions and public organizations to study the ethnic and political history of the Estonian and Crimean Tatar peoples and disseminate this knowledge among the world community members; monitoring the Crimean Tatars' and Estonians' rights fulfill in the occupied Crimea; joint preparation of appeals to international organizations in violation of the policy of the Russian occupation authorities in Crimea (in particular, the national one). These and other vectors of Ukrainian-Estonian cooperation can be aimed at accelerating the process of deoccupation of the Crimea and restoring Ukraine's control over an integral part of its territory.

An important factor of modernity, which, however, has historical roots and allows the Russian Federation to form additional ways of spreading the "Russian world" in the Baltics, is the existence of the Kaliningrad region nearby the Lithuanian borders. Having no land border with the main territory of the Russian Federation, this subject of the federation is kept not only in the administrative, but also in the cultural orbit of the Kremlin's influence. A similar situation occurred with Alaska, which was sold to the United States under the Treaty of 1867 due to the difficulty of maintaining ties with the imperial center due to the considerable territorial distance. Despite the higher level of communication available today, connections with the remote region still pose some problems for the federal government. However, Russia retains such territory in its composition, not intending to cede it. According to the official version, the German city of Koenigsberg became the Russian city of Kaliningrad in 1945 as a result of the postwar processes of division of the territories of Nazi Germany among the allies. This fact is quite true, but incomplete. Thus, during the Seven Years' War between the Russian and Prussian empires of 1756-1763, this city was captured by the Russian troops in 1758 and was being under their control until 1762. Until then, it was one of the classic medieval trading cities controlled by the Teutonic Knights. As in other similar cities in the Baltics, at its fairs, Moscow merchants abused their position and sold low-quality goods, instead of buying and bringing home various jewelry and precious metals for nothing. In general, the capture of the Baltic settlements by the Russians was characterized by the creation of a kind of audit commissions, which recorded all seized property and land and redistributed them among the local nobility. Moreover, at the time of the capture of Koenigsberg, the creation of the Copper Bank in the Russian Empire took place, for the work of which, of course, would not interfere with the resources obtained for nothing. At the same time, according to the statement of the then Russian
Chancellor O. Bestuzhev, the constant presence of a small Russian army corps in Europe was supposed to serve as an effective guarantee for preventing a possible war.

Thus, Koenigsberg was Russian for only four years, but this was enough for the Soviet political leadership to "return the original territory". In 1762, under the threat of losing the war, Emperor Peter III was forced to make concessions and return all the conquered territories of Prussia under a peace treaty. If this had not happened, the foreign policy interests of contemporary Russia would have required the preservation of the city in the orbit of imperial influence. It is essential that the Kaliningrad special area has been created as a structural unit of the Armed Forces of the Russian Federation. It includes the adjacent waters of the Baltic Sea and the airspace above it [9]. The Baltic Fleet Command exercises control over the area in order to "implement measures to prepare for armed defense in the area of responsibility. In total, the number of Russian troops in the Kaliningrad region exceeds 25,000 servicemen and 3,000 units of military equipment. In particular, after the annexation of the Crimea it was planned to transfer to Kaliningrad 4 additional army brigades from other regions of Russia. It was caused by the alleged fears of open invasion by neighboring Baltic states in response to the Crimean events [10]. There are also 3 higher military educational institutions and a cadet corps in Kaliningrad, which train personnel for various law enforcement agencies of the Russian Federation. In view of the above, it becomes clear that the importance of the Kaliningrad region for the Russian government lies, first of all, in strengthening its position to extend political influence to the Baltic countries and control the situation in Western Europe. The renunciation of the remnants of the socialist past by Lithuania, Latvia, and Estonia is for Russia nothing more than a threat of losing control of the region and any possibility of returning it to its influence.

In view of the above, it is obvious that the Kaliningrad region is the most convenient springboard for maintaining the ideology of the "Russian world" in the former Soviet republics. Thanks to the actions of the Stalinist leadership, the national composition of the population of this new Soviet region underwent significant changes after the Second World War due to the policy of russification. As a result, the historically German ethnic basis of the region was destroyed, which today makes it difficult to prove the doubts of the Russian origin of Königsberg. At the same time, examples of medieval knightly culture still remain as an integral part of the image of the city and its surroundings. Russia's overtly ignored principles of international law providing respect for state borders and territorial integrity, remain valid, however, and do not allow other civilized members of the world community to demand that the Putin government return historically German territory. The decision of the Potsdam Conference in 1945, according 
to which the Soviet Union gained possession of East Prussia and, consequently, Koenigsberg, was dictated by the policy of the victorious states to redistribute the possessions of Nazi Germany. Despite the fact that historical realities have changed significantly, this document remains valid. This necessitates the neutralization of a possible increase in Russia's influence in the Baltics with the help of resources located in the Kaliningrad region. The Ukrainian side can join the preparation of historical materials on Koenigsberg, as such activities are also aimed at the general weakening of Russia's position in the international arena, which is undoubtedly important for our country.

\section{CONCLUSIONS}

As in the case of Ukraine, the information component of the hybrid war has always been and remains one of the main methods of Russian expansion in the Baltic States.

\section{REFERENCES}

[1] Vermenych, J. (2020), "Theoretical and methodological determinants of the study of borders and border space", Ukrainian Historical Journal, no. 5. DOI: 10.15407/uhj2020.05.130

[2] Melnikova, L.V. (2020), Russian Orthodox Church and the wars of the Russian Empire in the nineteenth century, Russian.

[3] Kolesnik, I. (2020), "The phenomenon of backwardness from the perspective of global history", Ukrainian Historical Journal, no. 5, pp. 147-158. DOI: 10.15407/uhj2020.05.147

[4] Kirichenko, O.V. (2020), Post-communist transformation of the Republic of Latvia: lessons for Ukraine, Historical preconditions for the formation of the foreign policy orientation of the post-Soviet space: a collection of scientific papers, Ukrainian.

[5] Ivanov, O.Yu. (2017), "Political and legal design of the integration of the Crimean Khanate into the Russian Empire (1783 - mid-XIX century)" Bulletin of Taras Shevchenko National University of Kyiv, Legal sciences, no. 1 (104).
In general, the historical and ideological preconditions of Russian expansion in the Baltic States, which are important in terms of gaining experience in our country to counter Russian aggression at the present stage, can be represented as the following generalized model: territorial ("organic" closeness with Russia; "absence" of independent statehood; "progressive" role of Russia in cultural and economic development); religious expansion (support for the "natural" attraction of the Baltics to Orthodoxy; the "educational" mission of the Russian Orthodox Church; (pseudo) incentives for the local population to convert to the Orthodox faith); economic importance of the Baltics for Russia (direct trade with Europe; new urban centers; access to the Baltic Sea); cultural and assimilation policy (creation of new educational institutions; changes in the national composition of the population; language policy); foreign policy consolidation of the results of expansion (contractual pseudo-legitimation; "lightning expansion")

[6] Regional national and cultural autonomy of Estonians of the Republic of Crimea, available at: https://www.finnougoria.ru/community/nko/531/4 6145

[7] Ivanov, O.Yu. (2021), "From the history of Russian-Polish information confrontation: experience for Ukraine", Actual problems of information security management of the state, Ukrainian.

[8] Smoliy, V. Kulchytsky, S. and Yakubova, L. (2016), Donbass and Crimea: a place in the modern national project (analytical note). Ukrainian.

[9] Kaliningrad special district, available at: https://encyclopedia.mil.ru/encyclopedia/dictionar y/details_rvsn.htm?id=5867@morfDictionary

[10] Nikolsky A. Moscow will strengthen troops in the Kaliningrad region and the Baltic Fleet, available at: https://www.vedomosti.ru/politics/ articles / 2015/04/27 / moskva-usilit-voiska-vkaliningradskoi-oblasti-i-baltiiskii- flot 